\title{
Gene expression during preimplantation mouse development
}

\author{
Jay L. Rothstein, Dabney Johnson, Julie A. DeLoia, Jacek Skowronski, ${ }^{1}$ Davor Solter, ${ }^{2}$ \\ and Barbara Knowles
}

The Wistar Institute, Philadelphia, Pennsylvania 19104 USA; ${ }^{1}$ Cold Spring Harbor Laboratory, Cold Spring Harbor, New York 11724 USA

\begin{abstract}
To develop a resource for the identification and isolation of genes expressed in the early mammalian embryo, large and representative cDNA libraries were constructed from unfertilized eggs, and two-cell, eight-cell, and blastocyst-stage mouse embryos. Using these libraries, we now report the first stages at which the cytokines interleukin (IL)-6, IL-1 $\beta$, and interferon (IFN)- $\gamma$ are transcribed in the developing embryo and the presence of IL-7 transcripts in the unfertilized egg. Transcripts for IL-1 $\alpha,-2,-3,-4$, or -5 were not detected at these stages. To identify novel genes expressed on activation of the embryonic genome, the egg and eight-cell stage-specific cDNA libraries were subtracted from the two-cell library, yielding a specialized cDNA library enriched for transcripts expressed at the two-cell stage. Sequence and Southern blot analysis of several of these cDNAs expressed predominantly at the two-cell stage of embryogenesis revealed them to be from novel genes, thereby providing the first molecular tools with which to approach the study of gene expression in the early mammalian embryo.
\end{abstract}

Key Words: cDNA libraries; cytokines; interleukins; IFN- $\gamma$; PCR; preimplantation embryos; subtractive hybridization]

Received March 19, 1992; revised version accepted April 22, 1992.

The molecular control of mammalian preimplantation embryogenesis remains largely unexplored, due mainly to the difficulty of obtaining sufficient quantities of timed embryos for experimentation. Nonetheless, knowledge about the changes in gene expression that underlie this period is essential to understanding mammalian development. Several lines of evidence, most notably that inhibition of transcription at the one-cell stage blocks protein synthesis and all subsequent development after the first cleavage division, and that initiation of synthesis of all classes of RNA occurs at the two-cell stage, point to the early activation of the embryonic genome (for review, see Telford et al. 1990a). No resources existed that allowed investigation of whether activation leads to generalized gene transcription or synthesis of independent stage-specific transcripts. Temporal changes in transcription are also likely to herald the completion of cleavage and the formation of the first differentiated cells, those of the trophectoderm (for review, see Schultz 1986), whose origin and fate have been difficult to study without probes to lineage-specific markers. One approach to identifying genes relevant to mammalian development has focused on the sequence homology with genes of developmental importance in other vertebrate or invertebrate organisms. However,

${ }^{2}$ Present address: Max-Planck Institut für Immunobiologie, D-7800 Freiburg-Zähringen, Germany. considering that early development in mammals results in an implantation-competent embryo, it is likely that a unique combination of genes controlling this process will be utilized in the mammalian embryo. In an effort to identify genes expressed in these early mammalian developmental stages, several investigators have applied the polymerase chain reaction (PCR) technique, thus circumventing the problem of obtaining sufficient embryonic material for study (Rappolee et al. 1988). However, only transcripts of known genes can be readily identified with this technique. Classically, cDNA libraries have provided a useful resource for identifying novel genes transcribed in specific cell types or tissues. Yet for technical reasons, cDNA libraries prepared from unfertilized eggs or single stages of the preimplantation embryo (Taylor and Pikó 1987; Weng et al. 1989; Ko et al. 1990; Welsh et al. 1990) have not provided reliable sources for the comprehensive analysis of genes differentially expressed during early embryonic development.

Here, we describe the use of large and representative cDNA libraries constructed from poly $(A)^{+}$mRNA of preimplantation mouse embryos to demonstrate stagespecific transcription of several cytokines. Subtractive hybridization of these libraries served to identify cDNAs representing novel genes expressed in the two-cell-stage embryo. These libraries provide the first resource for molecular information about genes expressed in the egg and early embryonic stages and a tool to access novel genes 
expressed at the two-cell stage when the mouse embryonic genome is first activated.

\section{Results \\ Library and insert size of egg and embryonic cDNA libraries}

A single mouse egg or mouse embryo at any stage of preimplantation development contains no more than 50 pg of poly $(\mathrm{A})^{+}$mRNA (Clegg and Pikó 1983). We therefore optimized a cDNA cloning strategy to permit efficient library construction using 10-100 ng mRNA (J.L. Rothstein, D. Johnson, J. Jessee, J. Skowronski, D. Solter, and $\mathrm{B}$. Knowles, in prep.). Plasmid vectors, which can accommodate the directional cloning of cDNA, were employed so that T7 and T3 RNA polymerase promoter sequences could be used to generate sense and antisense transcripts for subtractive hybridization. Libraries containing $1 \times 10^{6}$ to $2 \times 10^{6}$ independent cDNA clones were constructed from the 50-175 ng of poly $(A)^{+}$RNA isolated from unfertilized eggs, and two-cell, eight-cell, and blastocyst-stage embryos (Table 1). Because a library of $10^{6}$ clones has a $>99 \%$ probability of including rare transcripts $(<10$ copies per cell) at a detectable frequency (Sambrook et al. 1989), these egg- and embryonic-stage libraries are not only likely to contain representatives of abundant but also of medium- and low-abundance transcripts in the egg or embryonic stage. Each of these four libraries contains at least $10^{6}$ independent cDNA clones (Table 1). The insert size of 25-50 randomly picked independent clones per library was determined by PCR, using primers to the $\mathrm{T} 3$ and $\mathrm{T} 7$ promoter sites in the cloning vector. Overall, the average insert sizes are unfertilized egg, $1.0 \mathrm{~kb}$; two-cell stage, $1.3 \mathrm{~kb}$; eight-cell stage, $0.7 \mathrm{~kb}$; and blastocyst, $1.0 \mathrm{~kb}$. The average size of an unfractionated population of mRNA molecules in the early embryo is estimated to be $\sim 2.0 \mathrm{~kb}$ /Clegg and Pikó 1983); thus, the chance of obtaining near full-length cDNAs is good in these libraries.

\section{Purity and representation of $c D N A$ libraries}

To determine whether the library inserts represent authentic mRNAs, each library was screened for the pres- ence of cDNAs representative of $28 \mathrm{~S} / 18 \mathrm{~S}$ rRNA. The abundance of mitochondria-encoded cytochrome- $c$ oxidase I and II was also examined to determine the level of contamination with mitochondrial messages. Very few to no detectable clones were identified that hybridized to these probes (Table 2), suggesting that the libraries contain $>99 \%$ poly $(A)^{+}$mRNA. To determine whether these libraries contained clones representative of genes known to be expressed at these stages of development, they were probed with a mouse $\beta$-actin cDNA. Between 200 and 355 of the 250,000 clones screened in each library hybridized with the $\beta$-actin probe (Table 2 ). These values, when converted (see Materials and methods), suggest that 18,700 actin mRNA molecules are present in the mouse egg and 5600 are present in the late twocell stage. We find that the levels of actin correspond well to those reported previously for the egg and two-cell stages, that is, 21,000 copies of actin mRNA in the egg and 3700 in the two-cell stage (Taylor and Pikó 1990), and are close to those of Bachvarova et al. (1989). We observe an increase in the number of actin transcripts in the eight-cell stage $(18,460)$ and blastocyst stages $(41,480)$, a pattern similar to previous reports (Taylor and Pikó 1990). The levels of actin in the libraries corroborate those of Taylor and Pikó and Bachvarova et al. and are substantially lower than the figures from comparable stages reported previously (Giebelhaus et al. 1983, 1985).

Transcripts of tissue-type plasminogen activator (t-PA) previously have been shown to decrease in maturing oocytes until they become nearly undetectable at ovulation (Huarte et al. 1985, 1987; Strickland et al. 1988). Expression of t-PA in the oocyte has been estimated at $<0.05 \%$ of the total mRNA (Huarte et al. 1987). To determine the representation of $\mathrm{t}-\mathrm{PA}$ in the unfertilized ovulated egg library, we hybridized a mouse t-PA cDNA clone (Rickles et al. 1988) to replica filters containing 250,000 clones and found that 60 , or $0.024 \%$, of the clones in the egg library were positive (Table 3 ). Three representative t-PA clones were partially sequenced from the $3^{\prime}$ end and found to be homologous to the $3^{\prime}$ untranslated region of the mouse t-PA gene cloned from the F9 teratocarcinoma-derived cell line (Rickles et al. 1988; data not shown). As expected, no t-PA cDNAs were detected in the two-cell, eight-cell, or blastocyst-

Table 1. Starting material and size of $c D N A$ libraries

\begin{tabular}{|c|c|c|c|c|c|}
\hline \multirow{2}{*}{$\begin{array}{l}\text { Embryonic } \\
\text { stage }\end{array}$} & \multirow{2}{*}{$\begin{array}{l}\text { Number } \\
\text { of } \\
\text { females }\end{array}$} & \multirow{2}{*}{$\begin{array}{l}\text { Number } \\
\text { of } \\
\text { embryos }\end{array}$} & \multicolumn{2}{|c|}{ RNA (ng) } & \multirow{2}{*}{$\begin{array}{l}\text { Library } \\
\text { size } \\
(\mathrm{cfu})^{\mathrm{b}}\end{array}$} \\
\hline & & & total & $\operatorname{poly}(A)^{\mathrm{a}}$ & \\
\hline Unfertilized egg & 200 & 5,000 & $1750^{c}$ & 175 & $2 \times 10^{6}$ \\
\hline Two-cell & 665 & 13,500 & $910^{d}$ & 46 & $1 \times 10^{6}$ \\
\hline Eight-cell & 300 & 2,778 & $1740^{d}$ & 87 & $2 \times 10^{6}$ \\
\hline Blastocyst & 100 & 600 & $900^{c}$ & 45 & $1 \times 10^{6}$ \\
\hline
\end{tabular}

${ }^{a}$ Estimate based on $5 \%$ poly $(\mathrm{A})^{+}$RNA.

${ }^{\mathrm{b}}$ Total number of independent cDNA clones (colony forming units) plated on primary filters.

'Amount of RNA calculated based on values of Pikó and Clegg (1982).

${ }^{\mathrm{d}}$ Values determined by use of Northern analysis of $18 \mathrm{~S} / 28 \mathrm{~S}$ rRNA in the embryonic samples compared with rRNA from a standard amount of cellular RNA. 
Table 2. Analysis of gene expression in CDNA libraries

\begin{tabular}{|c|c|c|c|}
\hline \multirow[b]{2}{*}{ cDNA library } & \multicolumn{3}{|c|}{ Probes $^{a}$} \\
\hline & $28 \mathrm{~S} / 18 \mathrm{~S}$ rRNA & $\begin{array}{l}\text { cytochrome-c } \\
\text { oxidase }\end{array}$ & $\beta$-actin \\
\hline Unfertilized egg & 0 & 0 & $275(0.110)$ \\
\hline Two-cell & 0 & $20\{0.008\}$ & $200(0.080)$ \\
\hline Eight-cell & $1(0.0004)^{\mathrm{b}}$ & 0 & $355(0.142)$ \\
\hline Blastocyst & 0 & 0 & $305(0.122)$ \\
\hline
\end{tabular}

${ }^{2}$ Probes used for hybridization are pA-28S/18S rRNA; cytochrome- $c$ oxidase I and II, and mouse $\beta$-actin isolated from a blastocyst-stage library (see Materials and methods).

${ }^{b}$ Number of positive colonies of 250,000 independent cDNA clones screened $(\%)$.

stage library $(0 / 250,000$ clones screened $)$; initiation of embryonic transcription of $\mathrm{t}-\mathrm{PA}$ has been reported previously to occur in the trophoblast at implantation (Huarte et al. 1985). Thus, the limited amount of t-PA cDNAs in these libraries is qualitatively and quantitatively consistent with previous information on transcription of this gene product.

The levels of highly expressed transcripts such as those of the intracisternal A-type particles (IAP; Lueders and Kuff 1980; Mietz et al. 1987) and B1/B2 repeat sequences (Kramerov et al. 1979; Krayev et al. 1980) have been analyzed previously in total embryonic RNA (Pikó et al. 1984; Taylor and Pikó 1987; Poznanski and Calarco 1991). We find that $0.035 \%$ of the clones in the egg library hybridized with an IAP probe (Pikó et al. 1984) or, by calculation, 5950 transcripts in the unfertilized egg are IAP. Similarly, $0.11 \%$ of the clones in the two-cell library or an estimated 7700 transcripts in the two-cellstage embryo, $0.021 \%$ of those in the eight-cell library or 2730 transcripts in the eight-cell-stage embryo, and $0.001 \%$ of those in the blastocyst library or 272 transcripts in the blastocyst, are IAP. These results are quantitatively comparable at the two-cell and similar at the eight-cell stage to those reported, previously, that is, 7100 IAP mRNA molecules in the two-cell-stage embryo and 9700 IAP mRNA molecules in the 8-cell-stage embryo (Pikó et al. 1984). IAP levels appear higher in the egg and lower in the blastocyst libraries than those reported, that is, 1300 mRNA molecules in the mouse egg and
37,900 mRNA molecules in the early blastocyst were estimated to be IAP (Pikó et al. 1984). The differences between the library data and that reported previously may reflect the known variation in IAP expression among mouse strains (Kuff and Fewell 1985) and/or the high percentage of nonadenylated IAP mRNA in the mouse blastocyst (Pikó et al. 1984), which would not be represented in the blastocyst cDNA library.

B1 and B2 repeat sequences are expressed abundantly in the preimplantation embryo (Taylor and Pikó 1987). These repeat sequences are found in the $5^{\prime}$ - or $3^{\prime}$-untranslated regions of RNA polymerase II-generated transcripts and as small $\left(\leqslant 500 \mathrm{bp}\right.$ ) poly $(\mathrm{A})^{+}$RNA polymerase III-dependent transcripts of unknown function (Kramerov et al. 1979; Krayev et al. 1980; Murphy et al. 1983). We find that the abundance of these transcripts increases dramatically in these libraries at the two-cell stage $(\sim 0.1-0.2 \%$ of the clones detected in the unfertilized egg vs. $2-4 \%$ of the clones detected in the two-cell stage; Table 3 - - values that are quantitatively similar to those reported previously (Vasseur et al. 1985; Taylor and Pikó 1987). Following this initial increase, B1 and B2 transcript levels decrease in the eight-cell and blastocyst libraries, a result at odds with those in the literature. However, the cDNAs used for library construction are derived from poly $(\mathrm{A})^{+}$RNA and are also size selected. Size selection would exclude the smaller polymerase IIIdependent $B 1$ and $B 2(\leqslant 500 \mathrm{bp})$ transcripts from these libraries; additional B1 sequences were found in uncloned cDNAs smaller than 500 bp (data not shown).

From this analysis of $\beta$-actin, t-PA, IAP, and B1/B2 repeats, genes known to be expressed in the egg and preimplantation embryonic stages, we conclude that these egg and embryonic cDNA libraries represent the transcripts present in the corresponding stages in vivo. Thus, the libraries provide an in vitro source of genes transcribed at these stages of development.

\section{Detection of cytokines in the $C D N A$ libraries}

As a first approach to identifying genes expressed during early embryogenesis that may have regulatory functions, we investigated the representation of several cytokines in the libraries. Studies of polypeptide growth factors in early mammalian development have focused on expres-

Table 3. Representativeness of gene expression in $c D N A$ libraries

\begin{tabular}{|c|c|c|c|c|}
\hline \multirow[b]{3}{*}{ cDNA library } & \multicolumn{4}{|c|}{ Probes $^{a}$} \\
\hline & \multirow[b]{2}{*}{$t-P A$} & \multirow[b]{2}{*}{ IAP } & \multicolumn{2}{|c|}{ repetitive elements } \\
\hline & & & $\mathrm{B} 1$ & $\mathrm{~B} 2$ \\
\hline Unfertilized egg & $60(0.024)^{b}$ & $88(0.035)$ & $26(0.130)$ & $30(0.150)$ \\
\hline Two-cell & 0 & $275(0.110)$ & $404\{2.020\}$ & $725(3.625)$ \\
\hline Eight-cell & 0 & $53(0.021)$ & $150\langle 0.750\rangle$ & $100(0.500)$ \\
\hline Blastocyst & 0 & $2(0.001)$ & $4\{0.020\}$ & $50(0.250)$ \\
\hline
\end{tabular}

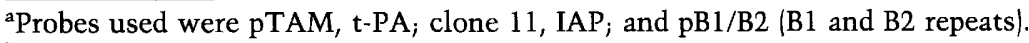

${ }^{\mathrm{b}}$ Number of positive clones when 250,000 colonies from each stage were screened with pTAM and clone 11 , or 20,000 independent cDNA clones were screened with $\mathrm{pB} 1 / \mathrm{B} 2(\%)$. 
sion of epidermal growth factor (EGF), transformation growth factor $(\mathrm{TGF}-\alpha)$, platelet-derived growth factor (PDGF), TGF- $\beta_{1}$, insulin-like growth factor (IGF)-I, and (IGF)-II at specific times during preimplantation development (Rappolee et al. 1988; Lee et al. 1990; Telford et al. 1990b). Although some of these growth factors are known to play a role in differentiation, their major function appears to involve regulation of the cell cycle. On the other hand, the cytokines not only regulate proliferation but also appear to induce differentiated functions. To investigate whether interleukins IL- $1 \alpha$, IL-1 $\beta$, IL-2-7, or $\gamma$-interferon (IFN- $\gamma$ ) are transcribed during preimplantation embryogenesis, the cDNA libraries from the unfertilized egg, eight-cell, and blastocyst stages were screened. Cytokine expression, identified initially by PCR analysis of pooled inserts from each cDNA library, was confirmed by direct screening of the cDNA libraries with authentic probes. PCR analysis of the libraries revealed expression of IL-1 $\beta$, IL- 6 , IL-7, and IFN- $\gamma$ but not IL-1 $\alpha$, or IL-2-IL-5 (Table 4). As expected, $\beta_{2}$ microglobulin $\left(\beta_{2} M\right)$ was present at all stages tested (Sawicki et al. 1981). Southern hybridization of the PCR gels using probes to IL-1 $\beta$, IL- 6, IL- 7, IFN- $\gamma$, and $\beta_{2} M$ verified the presence of these transcripts in the libraries (Fig. 1).

To quantify cytokine expression in the embryonic libraries, we screened each stage with a PCR-generated gene-specific probe. Screening 250,000 clones of each library with an IL-7 probe indicated 8 positive clones in the unfertilized egg library, whereas no colony hybridization was seen with the same number of clones from eight-cell and blastocyst libraries. Thus, IL-7 transcripts appear to be rare in the mouse egg $10.003 \%$ of the inde-

Table 4. PCR analysis of embryonic cytokine and $\beta_{2} M$ gene expression

\begin{tabular}{lccc}
\hline & \multicolumn{3}{c}{ Embryonic stage $^{\mathrm{a}}$} \\
\cline { 2 - 4 } Target gene & egg & eight-cell & blastocyst \\
\hline IL-1 $\alpha$ & - & - & - \\
IL-1 $\beta$ & - & - & + \\
IL-2 & - & - & - \\
IL-3 & - & - & - \\
IL-4 & - & - & - \\
IL-5 & - & - & - \\
IL-6 & - & + & + \\
IL-7 & + & - & - \\
IFN- $\gamma$ & - & - & + \\
$\beta_{2} M$ & + & + & + \\
\hline
\end{tabular}

aplated cDNA libraries were scraped, plasmid DNA was prepared by alkaline lysis, and cesium chloride-purified DNA was digested with MluI and SalI. Insert cDNA was isolated by agarose gel electrophoresis, and 10-25 ng was amplified by PCR by use of the indicated cytokine-specific oligonucleotide primers for $45 \mathrm{cycles}\left(94^{\circ} \mathrm{C}\right.$ for $30 \mathrm{sec}, 50^{\circ} \mathrm{C}$ for $30 \mathrm{sec}, 72^{\circ} \mathrm{C}$ for $\left.1 \mathrm{~min}\right)$. $1+\mid$ The presence of a specific signal for the indicated cytokine by Southern hybridization (see Fig. 1). All cytokine-specific primers were tested in RT-PCR reactions with total RNA derived from mouse peritoneal exudate and spleen cells, and were shown to give the appropriate size bands on EtBr-stained agarose gels (not shown).

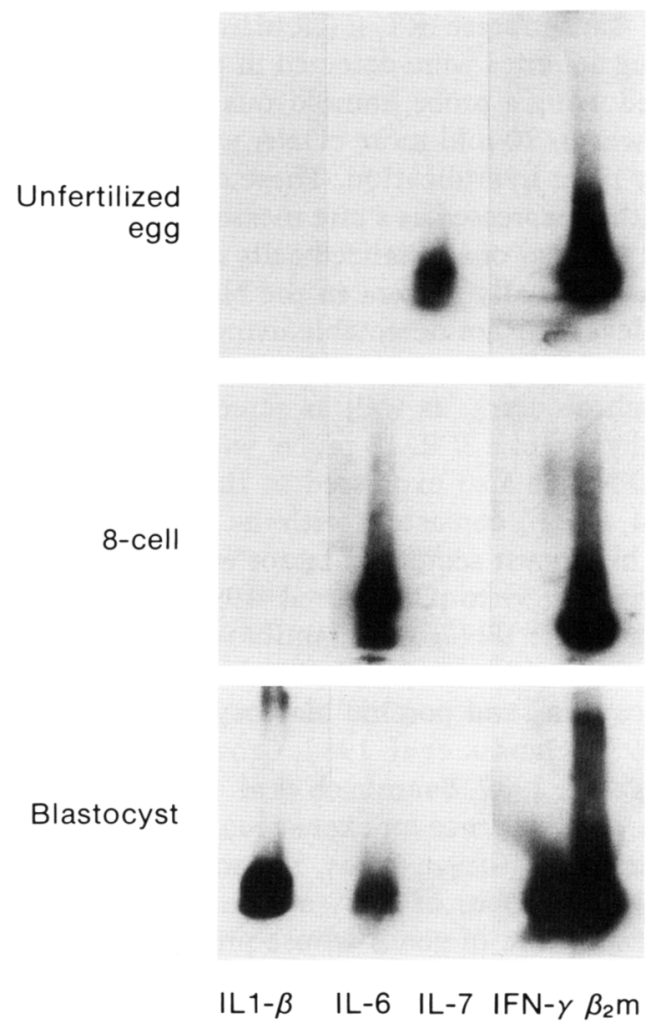

Figure 1. Southern hybridization of PCR-amplified cytokines following agarose gel electrophoresis. Individual PCR reaction mixtures using template from gel-purified, restriction enzymedigested cDNA from the libraries were electrophoresed on a $2.0 \%$ agarose gel, blotted onto nylon membrane, hybridized overnight in Church buffer at $65^{\circ} \mathrm{C}$ with $\left[{ }^{32} \mathrm{P}\right] \mathrm{dCTP}$-labeled cytokine-specific probes, washed, and exposed to X-ray film. Blots were stripped of probe and hybridized to another cytokine-specific probe. Shown is a composite of 1 -hr exposures from representative blots illustrating specificity of the PCR reaction from egg, eight-cell and blastocyst cDNA libraries with probes to IL-1 $\beta$, IL-6, IL-7, IFN- $\gamma$, and $\beta_{2} M$.

pendent cDNA clones in the library) and undetectable in the early embryo. Sequence analysis of two of the IL-7 hybridizing clones from the unfertilized egg library confirmed these to be the mouse IL-7 gene (Namen et al. 1988; data not shown). IL-6, a cytokine with effects on many cell types (Hirano et al. 1990; Sehgal 1990), was shown previously to be expressed at the blastocyst stage (Murray et al. 1990). Here, we report that IL-6 is transcribed as early as the eight-cell stage, persisting into the blastocyst stage (Table 4; Fig. 1). IL-1 $\beta$, a pleiotropic cytokine expressed by multiple cell types with an important role in the inflammatory response (Oppenheim et al. 1986; Dinarello 1989), is expressed by mammalian placental tissue and cultured trophoblast-derived cell lines (Taniguchi et al. 1991). The function of IL-1 $\beta$ in the developing embryo is not known, and there have been no reports of its synthesis during early embryonic development. Although IL-1 $\beta$ expression at the blastocyst stage was indicated by our PCR analysis of the libraries (Fig. 1) and by direct analysis of freshly isolated blastocysts by 
reverse transcriptase (RT)-PCR (data not shown), no hybridizing colonies were detected in the $5 \times 10^{5}$ colonies screened using a probe homologous to the $5^{\prime}$ end of IL$1 \beta$. However, 20 -fold more cDNA was screened by PCR than by filter hybridization. These data suggest that IL$1 \beta$ is either expressed as a rare message in each cell or by a small number of specialized cells in the mouse blastocyst, or is actually present in the blastocyst library at a higher level but not detectable using the $5^{\prime}$ IL- $1 \beta$ probe. Analysis of IL-1 $\beta$ expression in the inner cell mass and the trophectoderm, as well as screening the blastocyst library by use of a $3^{\prime}$ IL- $1 \beta$ probe, will likely resolve this issue. IFN- $\gamma$ is also expressed in the mouse blastocyst (Table 4; Fig. 1 ), consistent with the observation that the mouse blastocyst secretes a factor with IFN-like antiviral activity in vitro (Cross et al. 1990; Nieder 1990). A member of the IFN $-\alpha$ gene family was identified previously as one of the major proteins expressed by bovine, ovine, caprine, and porcine blastocysts (Imakawa et al. 1987, 1989; Hansen et al. 1988; Cross and Roberts 1989; Roberts et al. 1989; Baumbach et al. 1990). Our data provide the first evidence for expression of any interferon in the murine blastocyst. Thus, the screening of these libraries with probes of known cytokines demonstrates the transcription of genes whose products are often expressed in differentiated cell types and mediate changes in gene expression.

\section{Isolation of novel stage-specific genes by subtractive hybridization}

To identify genes whose expression changes during preimplantation development, we generated specialized libraries by subtractive techniques. Directional cloning in the Bluescript vector allowed us to use a modification of the biotin-streptavidin method (Sive and St. John 1988; J.L. Rothstein, D. Johnson, J. Jessee, J. Skowronski, D. Solter, and B. Knowles, in prep.) to obtain unique mRNA molecules. T3-initiated, biotinylated, antisense singlestranded, and hybrid RNA molecules were separated from T7-initiated, sense single-stranded molecules after binding to streptavidin (Fig. 2). Using this approach, we generated a two-cell-specific subtraction library by hybridizing a fivefold excess of biotinylated RNA from the egg library to that of the two-cell library. The resulting two-cell-specific single-stranded RNA was separated from biotinylated RNA bound to streptavidin, and hybridized to a 10-fold excess of biotinylated RNA from the eight-cell library. Following a second streptavidin treatment, the remaining single-stranded RNA was reversetranscribed and cloned into plasmid vectors. The average insert size of the cDNAs in the two-cell subtraction library (2CSL-I), which contains $2 \times 10^{6}$ clones, was 1.0 $\mathrm{kb}$ (data not shown). Repeating the procedure schematized in Figure 2 with the 2CSL-I library as starting material resulted in a second two-cell-specific subtraction library (2CSL-II) of $2 \times 10^{7}$ clones with an average insert size of $300-400 \mathrm{bp}$ (data not shown). The smaller size of the cDNAs in the 2CSL-II library is consistent with RNA degradation during the multiple and long incuba- tion periods of double-stranded RNA hybrids at high temperatures.

To determine whether these subtraction libraries are reduced in complexity, we hybridized both subtracted libraries with probes to IAP, $\beta$-actin, and $\mathrm{B} 1 / \mathrm{B} 2$ repeat sequences; no positive hybridization was detected in either subtraction library $(250,000$ clones screened; data not shown). Because cDNAs in the 2CSL-I and -II libraries should be highly enriched for transcripts expressed in greatest abundance at the two-cell stage of embryogenesis, we randomly selected clones for further analysis. Twenty such clones with inserts $\geqslant 500 \mathrm{bp}$ in length were partially sequenced and compared with those listed in the GenBank/EMBL data bases. Of these 20 clones, 14 did not match any sequence listed in the data bases. The other six clones proved to be bacterial cDNAs, most likely from the Escherichia coli tRNA used as a carrier in the preparation of the subtraction libraries. Following sequence analysis, the 14 unique cDNAs were hybridized to the original two-cell cDNA library and any clones that showed specific hybridization were analyzed further for stage-specific expression by hybridization to the egg and eight-cell libraries. In this manner, four stage-specific cDNAs were identified that were expressed predominantly or exclusively at the two-cell stage of preimplantation development (Table 5). One clone, stagespecific embryonic clone-3 (SSEC-3), appears to be expressed predominantly at the two-cell stage, with a low number of hybridizing clones ( 3 hybridizing clones/ 250,000 colonies screened) in the egg library. SSEC-D is a highly expressed message; $0.16 \%$ of the clones in the two-cell library hybridized with this cDNA, approximately fivefold more than in the egg library. SSEC-C is two-cell specific, but only $0.002 \%$ of the colonies screened hybridized with this cDNA. There are more colonies hybridizing with the SSEC-P probe in the twocell-stage library $(0.02 \%)$ than in the egg $(0.01 \%)$, suggesting that this gene is either newly transcribed at the two-cell stage or that its message is somehow protected during the generalized RNA degradation that occurs after fertilization (Clegg and Pikó 1983). Each of these clones represents an authentic single-copy mouse gene as determined by Southern analysis (data not shown). In addition, expression of SSEC-C, SSEC-D, and SSEC-P was confirmed by direct RT-PCR analysis of freshly isolated two-cell embryos using SSEC-specific primers (data not shown). Since SSEC-3, SSEC-C, SSEC-D, and SSEC-P are small cDNAs without apparent open reading frames, isolation of full-length cDNAs corresponding to these clones is a necessary and an ongoing effort. All of the remaining 14 cDNAs were confirmed by Southern blot hybridization to be of mouse origin, but were not detected in the two-cell library after screening 250,000 clones and, therefore, are likely to represent extremely rare transcripts.

\section{Discussion}

The unfertilized egg and embryonic stage-specific cDNA libraries we have described provide a unique resource to 

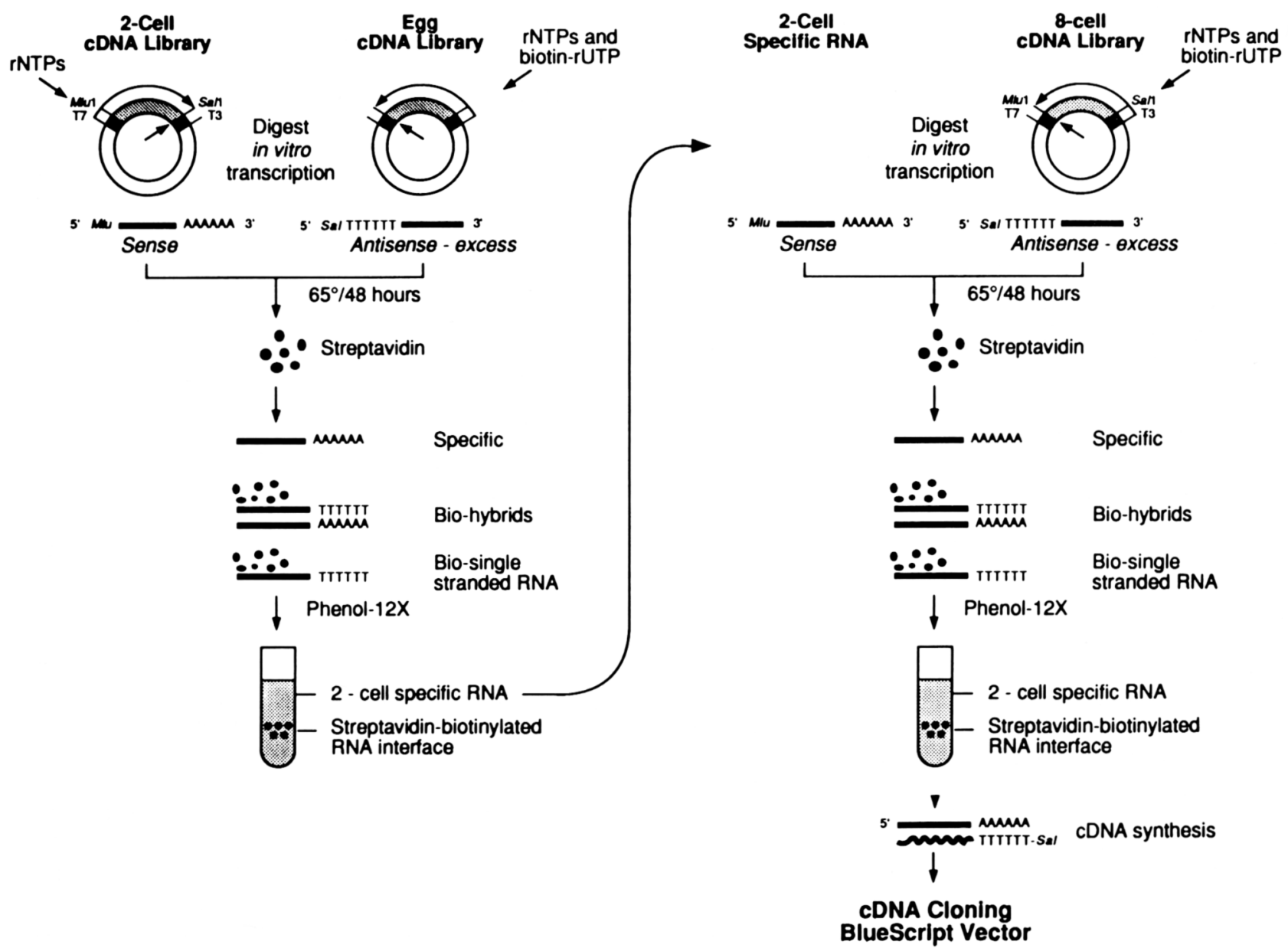

Figure 2. Scheme for the generation of primary subtractive cDNA libraries (2CSL-I). For secondary subtractive libraries, the entire procedure was repeated with sense transcripts from 2CSL-I to yield 2CSL-II. Phenol extraction of the hybridized streptavidin-treated RNA leaves the two-cell-specific RNA in the aqueous phase for use in cDNA cloning. Sense RNA was synthesized from the linearized two-cell library and hybridized to a fivefold excess of antisense biotinylated RNA from the egg library. The RNA remaining after streptavidin treatment was subsequently hybridized to a 10-fold excess of RNA transcribed from the eight-cell library. RNA left in the aqueous phase was used to make a cDNA library (2CSL-I). This subtraction library was used to make a second subtraction library by hybridizing the sense RNA transcribed from this subtraction library to a 10-fold excess of the biotinylated antisense RNA transcribed from the egg library. The RNA isolated in the aqueous phase was hybridized further to a 10-fold excess of the biotinylated antisense RNA transcribed from the eight-cell library, and a cDNA library was constructed from the remaining two-cell-specific RNA as described previously (2CSL-II).

study genes expressed in the early mammalian embryo. The results obtained by probing these libraries with single-copy genes suggest that they are representative of the genes transcribed at these stages. One aspect of this analysis is that our estimate of actin levels will serve to resolve the controversy over the quantity of actin message in the preimplantation embryo. Previous estimates of actin mRNA abundance were made by comparing the level of embryonic actin mRNA to that in mRNA from a nonembryonic standard source, a technique subject to variation. Quantitation of independent actin clones in cDNA libraries overcomes this limitation. Another interesting aspect arises from the difference between $\mathrm{Bl}$ and B2 transcript levels in the unfertilized egg and twocell-stage libraries on the one hand, and the eight-celland blastocyst-stage libraries on the other. Previous studies of total unfractionated RNA revealed an increase in $\mathrm{B} 1$ and $\mathrm{B} 2$ repeat-containing transcripts throughout preimplantation development (Taylor and Pikó 1987; Pozanski and Calarco 1991), whereas the frequency of B1 and $\mathrm{B} 2$ repeat-containing $\mathrm{CDNAs}$ decreases in the libraries after the two-cell stage. These data suggest that there may be changes in the RNA polymerase II and III activity in the embryo after the activation of the embryonic genome at the two-cell stage. Previous studies have suggested that changes occur in the relative amounts of RNA polymerase II and III activity between the eightcell stage and blastocyst, the earliest embryonic stages investigated (Warner 1977).

The expression of polypeptide growth factors was investigated because the interactions of these factors with their receptors mediate changes in gene expression, re- 
Table 5. cDNA clones obtained from two-cell subtraction library

\begin{tabular}{|c|c|c|c|c|c|}
\hline \multirow[b]{2}{*}{ Clone } & \multirow{2}{*}{$\begin{array}{l}\text { cDNA } \\
\text { insert } \\
\text { size }(b p)^{a}\end{array}$} & \multicolumn{3}{|c|}{$\begin{array}{l}\text { Positive clones } \\
\text { (\% expression })^{\mathrm{b}}\end{array}$} & \multirow{2}{*}{$\begin{array}{c}\begin{array}{c}\text { Sequence } \\
\text { information }\end{array} \\
\text { length }(b p)\end{array}$} \\
\hline & & egg & two-cell & eight-cell & \\
\hline SSEC-3 & 500 & $3(0.001)$ & $10(0.004)$ & 0 & 320 \\
\hline SSEC-C & 600 & 0 & $5(0.002)$ & 0 & 300 \\
\hline SSEC-D & 600 & $75(0.030)$ & $400\{0.160\}$ & $10(0.004)$ & 382 \\
\hline SSEC-P & 900 & $25(0.010)$ & $50\{0.020\}$ & 0 & 172 \\
\hline
\end{tabular}

${ }^{a}$ Approximate size based on agarose gel ( $\phi$ X 174 standard).

${ }^{b}$ Number of positive colonies detected of 250,000 independent cDNA clones screened.

'Obtained from combining partial 3 ' and 5' sequence of each clone. Nucleotide sequences were found to be novel when compared with those listed in GenBank/EMBL by use of WORDSEARCH and FASTA commands of the GCG software program (Devereux et al. 1984).

sulting in differentiation or proliferation. Our analysis of these libraries provides the first evidence for differential expression of several differentiation-inducing cytokines in the early embryo. Moreover, in the unfertilized egg, we detected transcripts for IL-7, a factor known to induce the differentiation of immature lymphocytes (Henney 1989 ) and to activate directly growth regulatory genes such as N-myc and c-myc (Morrow et al. 1992). Identification of the functional protein in the egg and of the IL-7 receptor in the ovary, spermatozoa, or embryo will be key to determining whether IL-7 has a role in oogenesis, fertilization, and/or in early embryonic development. Interestingly, by the eight-cell stage, we find transcription of IL-6, which is known to induce expression of several other genes including IL-1 (Lotem et al. 1991). We find IL-1 $\beta$, itself a pleiotropic differentiative factor capable of inducing the expression of other genes (Oppenheim et al. 1986), in the mouse blastocyst. IL-1 has been detected in the trophoblast and placental tissue of murine embryos and later stage human fetuses (Flynn et al. 1982; Crainie et al. 1990; Masuhiro et al. 1991; Taniguchi et al. 1991), suggesting that the trophectoderm of the blastocyst, the first differentiated cell type of the embryo, may be the cell type in the blastocyst responsible for the observed IL-1 $\beta$ expression. At the blastocyst stage, we also detect transcripts of IFN- $\gamma$, a product of T lymphocytes that provides an inductive signal to alter gene expression. The role of IFN- $\gamma$ in implantation and embryogenesis awaits further experimentation. Thus, this analysis indicates that genes whose products are known to alter the transcription in differentiated cells are sequentially transcribed prior to and at the time of the formation of the first differentiated cell type in the embryo.

The capacity to generate specialized subtractive cDNA libraries provides access to mammalian genes expressed at a predetermined temporal or spatial coordinate. These embryonic cDNA libraries will now serve as the starting point for the generation of a series of subtraction libraries enabling identification of stage-specific genes. The first of these libraries, enriched for genes expressed at the two-cell stage of embryogenesis, has been successfully constructed; of the first 20 cDNA clones investigated, 14 novel mammalian genes were identified. Ten of these clones represent rare transcripts, and the other 4 , or $20 \%$, are expressed predominantly at the twocell stage. The results obtained using these subtraction libraries demonstrate the feasibility of this approach in identifying novel cDNA probes for genes whose transcription changes during development, and in isolating novel cDNA clones of relatively rare transcripts from a specific embryonic stage.

Because each cDNA library described in this report is representative, it should contain at least one cDNA clone of most of the genes transcribed in the corresponding stage in the mouse. Thus, by using probes derived from known genes and new probes isolated by such techniques as subtraction, the libraries provide the much needed instrument to determine whether the genes transcribed at the two-cell stage are activated independently to perform a stage-specific function or whether most of the embryonic genome is transcriptionally activated at the two-cell stage and, on differentiation, enhanced expression or specific repression of specific gene subsets occurs. Although few studies have directly addressed either notion, the generalized decrease in methylation during preimplantation mouse development (Monk et al. 1987) suggests a global activation of the embryonic genome. Similarly, the low-level constitutive expression of cell-lineage-specific genes, such as myoD and other mesoderm-associated genes (Rupp and Weintraub 1991), at the time when the frog embryonic genome is first activated, also supports the generalized activation hypothesis. The availability of cDNA libraries representing serial stages of early mouse development may now allow this basic issue to be experimentally addressed in the earliest embryonic stages.

\section{Materials and methods}

Mice and embryo recovery

Unfertilized eggs, two-cell, eight-cell, and blastocyst embryos were collected from immature B6D2F $F_{1}$ mice (Jackson Laboratories, Bar Harbor, ME or Harlan-Spague Dawley, Indianapolis, IN) after superovulation (Hogan et al. 1986) and mating to $\mathrm{B}_{6} 2 \mathrm{~F}_{1}$ males, where appropriate. Unfertilized eggs were treated with hyaluronidase and subsequently with Pronase, whereas cleavage-stage embryos and blastocysts were treated with Pronase alone (Hogan et al. 1986). Eggs and embryos from all stages were washed repeatedly in modified Whitten's medium (Abramczuk et al. 1977), and pools of 500-1000 were 
placed in $200 \mu \mathrm{l}$ of embryo lysis buffer [ELB: $100 \mathrm{~mm} \mathrm{NaCl}, 50$ mM Tris- $\mathrm{HCl}(\mathrm{pH} 7.5), 5 \mathrm{~mm}$ EDTA, $0.5 \%$ SDS, $5 \mu \mathrm{g}$ of $E$. coli tRNA, (Boehringer Mannheim)], which had been initially incubated with $0.5 \mathrm{mg} / \mathrm{ml}$ of proteinase $\mathrm{K}$ (Boehringer Mannheim) for $30 \mathrm{~min}$ at $37^{\circ} \mathrm{C}$ to remove any contaminating RNase.

\section{Embryo RNA isolation}

The embryo/ELB solution was incubated for $1 \mathrm{hr}$ at $37^{\circ} \mathrm{C}$ and extracted twice with phenol-chloroform, and nucleic acids were collected by ethanol precipitation and stored at $-70^{\circ} \mathrm{C}$ in absolute ethanol (Sambrook et al. 1989). Aliquots were removed and microcentrifuged for $60 \mathrm{~min}$. The $70 \%$ ethanol-washed pellet was air-dried, redissolved in $80 \mu \mathrm{l}$ of RNase-free water and 20 $\mu l$ of $5 \times$ DNase buffer [ $250 \mathrm{~mm}$ Tris- $\mathrm{HCl}(\mathrm{pH} 7.5), 1 \mathrm{M} \mathrm{NaCl}, 50$ $\mathrm{mM} \mathrm{MgCl}, 25 \mathrm{~mm} \mathrm{CaCl}_{2}$ ], and $1.5 \mu \mathrm{g}$ of DNase I (Worthington Biochemicals), which was initially incubated with $0.5 \mathrm{mg} / \mathrm{ml}$ of proteinase $\mathrm{K}$ (Boehringer Mannheim) at $37^{\circ} \mathrm{C}$ for $30 \mathrm{~min}$ to remove contaminating RNase, was added and the sample was incubated at $37^{\circ} \mathrm{C}$ for $30 \mathrm{~min}$. DNase digestion was terminated by adding $10 \mu \mathrm{l}$ of $0.25 \mathrm{M}$ trans-1,2-diaminocyclohexane$N, N, N^{\prime}, N^{\prime}$-tetraacetic acid monohydrate (CDTA), $5 \mu l$ of $10 \%$ SDS, and $2 \mu \mathrm{l}$ of proteinase $\mathrm{K}(20 \mathrm{mg} / \mathrm{ml})$ and incubated for 15 $\min$ at $56^{\circ} \mathrm{C}$. The solution was extracted twice with phenolchloroform, and total embryonic RNA was ethanol precipitated. Poly $(\mathrm{A})^{+}$mRNA was selected using poly $(\mathrm{dU})-$ Sephadex according to the manufacturer's protocol (GIBCO/BRL). Briefly, 20-50 $\mathrm{mg}$ of poly(dU)-Sephadex beads were resuspended in $1 \mathrm{ml}$ of NTS [20 mM Tris- $\mathrm{HCl}(\mathrm{pH} 7.5), 1 \mathrm{~mm}$ EDTA, 0.2\% SDS, $0.4 \mathrm{M}$ $\mathrm{NaCl}]$ in a $1.5-\mathrm{ml}$ microcentrifuge tube, swollen, and spun briefly. Beads were washed three times with $1 \mathrm{ml}$ of NTS before an equal volume of NTS was added to the packed beads. DNasetreated total embryonic RNAs were pelleted and resuspended in 20-25 $\mu$ l of RNase-free $\mathrm{H}_{2} \mathrm{O}$. RNA aliquots from a given stage were pooled and added to an equal volume of $2 \times$ NTS, mixed, added to the washed poly(dU)-Sephadex beads, and agitated lightly for 10-20 min. Unbound RNA was removed by three washes with $1 \mathrm{ml}$ of NTS and a single wash with low-salt NTS $(0.1 \mathrm{M} \mathrm{NaCl})$. Bound poly $(\mathrm{A})^{+}$RNA was eluted from the beads by addition of $50 \mu$ l of EL [0.1\% SDS, $20 \mathrm{mM}$ Tris- $\mathrm{HCl}(\mathrm{pH} 7.5)$, $1 \mathrm{~mm}$ EDTA, $90 \%$ deionized formamide] and gentle agitation at room temperature for $10 \mathrm{~min}$. The supernatant from the pelleted beads was transferred to a tube containing $200 \mu \mathrm{l}$ of chloroform and $5 \mu \mathrm{g}$ of tRNA carrier, and extracted, and the aqueous phase was recovered. Two volumes of ethanol were added; and following incubation for several hours at $-70^{\circ} \mathrm{C}$, RNA was pelleted by a 1 -hr centrifugation. After washing with $70 \%$ ethanol, the pellet was air-dried, resuspended in $8.3 \mu \mathrm{l}$ of RNase-free water, and stored at $-70^{\circ} \mathrm{C}$.

\section{RNA quantification}

RNA was quantified by visually comparing the amount of RNA in $1 \%$ of each embryo sample to serial dilutions of cellular RNA standards on Northern blots (Sambrook et al. 1989) after hybridization to a random-primed (Feinberg and Vogelstein 1983) $\left[{ }^{32} \mathrm{P}\right] \mathrm{dCTP}$-labeled $28 \mathrm{~S} / 18 \mathrm{~S}$ ribosomal probe (gift of James Sylvester, University of Pennsylvania, Philadelphia, PA). The level of poly $(\mathrm{A})^{+}$mRNA was estimated as $\sim 5 \%$ of the total mRNA (Pikó and Clegg 1982; Giebelhaus et al. 1983).

\section{cDNA synthesis}

First- and second-strand cDNA syntheses were performed by modification of the method described (Gubler and Hoffman 1983). RNA in $8.3 \mu \mathrm{l}$ of $\mathrm{H}_{2} \mathrm{O}$ was heated to $65^{\circ} \mathrm{C}$ for $15 \mathrm{~min}$ to remove secondary structure and placed immediately on ice. All first-strand reaction mixtures were assembled on ice in a total volume of $33 \mu \mathrm{l}$. Each reaction contained $6.6 \mu \mathrm{l}$ of $5 \times$ reverse transcriptase buffer (GIBCO/BRL), $3.3 \mu \mathrm{l}$ of $10 \mathrm{mM}$ dNTPs (Pharmacia), 500 ng of oligo(dT)/SalI linker primer (Wistar Institute Nucleotide Synthesis Facility, 5'-CGGTCGACCGTCGACCG $\left.(\mathrm{T})_{15^{-}} 3^{\prime}\right], 1.3 \mu \mathrm{l}$ of BSA $\left(2.4 \mathrm{mg} / \mathrm{ml}^{\text {; }}\right.$ Boehringer Mannheim), 1 unit of human placental RNase inhibitor (Boehringer Mannheim), $50 \mu \mathrm{Ci}$ of $\left.{ }^{32} \mathrm{P}\right] \mathrm{dCTP}(3000 \mathrm{mCi} / \mathrm{mm}$, Amersham), and 200 units of Superscript $\mathrm{RNase}^{-}$Moloney murine leukemia virus (MMLV) RT (GIBCO/BRL). The sample was then incubated at $37^{\circ} \mathrm{C}$ for $60 \mathrm{~min}$. The amount of RNA converted to cDNA was quantified as described (Sambrook et al. 1989) and was consistently $30 \pm 8 \%$. Second-strand synthesis was performed in the same tube in a total volume of $200 \mu \mathrm{l}$. Briefly, 30 $\mu \mathrm{l}$ of first-strand reaction, $20 \mu \mathrm{l}$ of $10 \times$ second-strand buffer (Sambrook et al. 1989), 2 units of RNase H (Pharmacia), 70 units of DNA polymerase I holoenzyme (Boehringer Mannheim), 20 $\mu \mathrm{l}$ of dNTPs (10 mM each), and sterile, nuclease-free $\mathrm{H}_{2} \mathrm{O}$ were incubated for $1 \mathrm{hr}$ at $15^{\circ} \mathrm{C}$, followed by $1 \mathrm{hr}$ at room temperature. The reaction was terminated by the addition of $2.5 \mu \mathrm{l}$ of $0.25 \mathrm{M}$ CDTA, $5 \mu \mathrm{l}$ of glycogen $(1 \mathrm{mg} / \mathrm{ml}$; Boehringer Mannheim), $7 \mu \mathrm{l}$ of $10 \%$ SDS, and $50 \mu \mathrm{g}$ of proteinase $\mathrm{K}$, followed by a 15 -min incubation at $56^{\circ} \mathrm{C}$. Following phenol-chloroform extraction, addition of an equal volume of $5 \mathrm{M} \mathrm{NH}_{4} \mathrm{OAc}$, and ethanol precipitation, $\mathrm{S} 1$ nuclease treatment of double-stranded cDNA was performed (Gubler and Hoffman 1983) in a total volume of $100 \mu \mathrm{l}$ with 200 units of S1 nuclease (Boehringer Mannheim) in $1 \times \mathrm{S} 1$ buffer $(0.1 \mathrm{M} \mathrm{NaOAc}, 0.8 \mathrm{M} \mathrm{NaCl}, 2 \mathrm{~mm}$ $\mathrm{ZnCl}_{2}$ l, for $20 \mathrm{~min}$ at $37^{\circ} \mathrm{C}$. Nuclease reactions were terminated by adding $20 \mathrm{~mm}$ Tris- $\mathrm{HCl}$ (pH 8.3), followed by phenol extraction and ethanol precipitation. Nuclease-treated cDNA was end repaired by resuspension in $11 \mu \mathrm{l}$ of nuclease-free $\mathrm{H}_{2} \mathrm{O}, 4 \mu \mathrm{l}$ of $5 \times \mathrm{T} 4$ polymerase buffer $[0.2 \mathrm{M}$ Tris $-\mathrm{HCl}(\mathrm{pH} 7.5), 50 \mathrm{~mm}$ $\mathrm{MgCl}_{2}, 10 \mathrm{~mm}$ EDTA, $40 \mathrm{~mm}$ DTT, $1 \mathrm{mg} / \mathrm{ml}$ of BSA], $4 \mu \mathrm{l}$ of dNTPs (10 mM each), 1 unit of T4 polymerase (Boehringer Mannheim), and incubation at $37^{\circ} \mathrm{C}$ for $15 \mathrm{~min}$ (Sambrook et al. 1989). End-repaired cDNA was phenol/chloroform-extracted and ethanol-precipitated. 5'-Phosphorylated MluI linkers $(3 \mu \mathrm{g}$, Pharmacia LKB Biotechnology) were ligated to blunt-ended cDNA by use of 1 Weiss unit of T4 ligase in $30 \mu \mathrm{l}$ for $16-18 \mathrm{hr}$ at $15^{\circ} \mathrm{C}$ (Sambrook et al. 1989). Ligase was inactivated $\left(65^{\circ} \mathrm{C}\right.$ for $10 \mathrm{~min}$ ), and the cDNA was double-digested with the restriction enzymes SalI and MluI (New England Biolabs) in a total volume of $400 \mu \mathrm{l}$ for $5-6 \mathrm{hr}$ at $37^{\circ} \mathrm{C}$, under conditions suggested by the manufacturer. Digestion reactions were terminated, phenol/ chloroform-extracted, and ethanol-precipitated as described above. Digested cDNA was resuspended in $15 \mu \mathrm{l}$ of nucleasefree $\mathrm{H}_{2} \mathrm{O}, 10 \mu \mathrm{l}$ of saturated urea, and $1 \mu \mathrm{l}$ of bromphenol blue tracer dye $(1 \mathrm{mg} / \mathrm{ml})$ and loaded onto a $1-\mathrm{ml}$ Sepharose CL4B column (Pharmacia) initially washed in column buffer $[20 \mathrm{mM}$ Tris- $\mathrm{HCl}$ (pH 7.5), $0.2 \mathrm{~m} \mathrm{NaOAc}, 4$ mM EDTA, 0.1\% SDS]. Fractions of 100-200 $\mu$ l were collected; cDNA $>500$ bp eluted in the first radioactive peaks. After counting, the peak fractions were pooled and cDNA was precipitated with ethanol using $15 \mu \mathrm{g}$ of glycogen as carrier. Precipitated cDNA was resuspended in water to a concentration of $0.25-1 \mathrm{ng} / \mu \mathrm{l}$ and ligated into an excess of linearized $\mathrm{pBS}$ vector for $18 \mathrm{hr}$ at $15^{\circ} \mathrm{C}$ (Stratagene, modified so that the EcoRI site was converted to an MluI site, and the HindIII site was converted to a SalI sitel. Ligation reactions were phenol/chloroform-extracted, ethanol-precipitated, and resuspended in $10 \mu \mathrm{l}$ of $\mathrm{TE}$ [10 $\mathrm{mm}$ Tris- $\mathrm{HCl}(\mathrm{pH} 7.5), 0.1 \mathrm{mM}$ EDTA] prior to bacterial electroporation.

Bacterial electroporation, plating, and composition of $c D N A$ libraries

E. coli strain $\mathrm{DH} 10 \mathrm{~B}$ was kindly provided by Joel Jessee 
(GIBCO/BRL). Bacteria used for electroporation were grown and made electrocompetent as described (Hanahan et al. 1991). All electroporations were performed by use of a Cell Porator (GIBCO/BRL) set at $400 \mathrm{~V}$ and $4000 \mathrm{ohms}$ (resulting in line voltages of $2.4-2.5 \mathrm{kV}$ ). Electrotransformation efficiencies of $3 \times 10^{10}$ to $6 \times 10^{10} \mathrm{cfu} / \mu \mathrm{g}$ of plasmid were routinely obtained with $10 \mathrm{pg}$ of pUC19. Electroporation of cDNA libraries resulted in transformation efficiencies of $2 \times 10^{8}$ to $3 \times 10^{8} \mathrm{cfu} /$ $\mu \mathrm{g}$ of cDNA. cDNA was electroporated in independent aliquots containing $1 \mu \mathrm{l}$ of cDNA and $25 \mu \mathrm{l}$ of electrocompetent bacteria. Aliquots were electroporated, grown in $1 \mathrm{ml}$ of SOC medium (Hanahan et al. 1991) at $37^{\circ} \mathrm{C}$ for $60 \mathrm{~min}$, pooled, and spun at $400 \mathrm{~g}$ for $10 \mathrm{~min}$. Cell pellets were resuspended in $1 \mathrm{ml}$ of SOC for every 250,000 estimated transformants, and each milliliter was spread onto $8.5 \times 8.5$-inch MSI nylon membranes that were placed on top of LB/Amp agar plates (Sambrook et al. 1989) and incubated overnight at $37^{\circ} \mathrm{C}$. The following day, filters were replica-plated and prepared for hybridization, and master filters were stored at $-70^{\circ} \mathrm{C}$ (Rothstein et al. 1992). For all libraries, additional plates were scraped with $20 \mathrm{ml}$ of LB/Amp, and 0.1to $0.5-\mathrm{ml}$ aliquots were stored at $-70^{\circ} \mathrm{C}$.

\section{Genetic probes and reagents}

Probes used in this study were: pTAM (full-length t-PA cDNA), a kind gift from S. Strickland (State University of New York at Stony Brook); clone 11 (genomic clone containing the 5' LTR and coding regions of a mouse IAP gene); and mitochondrial cytochrome-c oxidase I and II cDNA clone (Pikó and Taylor 1981), kindly provided by L. Pikó (Veterans Administration Hospital, Sepulveda, CA); murine B1/B2 cDNA probe (Larin et al. 1991), a kind gift from M. Bucán (University of Pennsylvania, Philadelphia, PA|. We isolated the murine $\beta$-actin cDNA clone from a mouse blastocyst library using a chicken $\beta$-actin cDNA (Alonso et al. 1986). The full-length murine IL-7 cDNA probe was kindly provided by S. Gillis and L. Park (Immunex, Seattle, WA). PCR primer sets specific for the central and 5 ' regions of mouse IL-1-IL-7 and IFN- $\gamma$ genes were purchased from Clonetech Laboratories. Radioactive probes were obtained by isolating inserts from plasmids by appropriate restriction enzyme digestion, agarose gel purification, and ${ }^{32} \mathrm{p}$-labeling by use of the random primer method (Feinberg and Vogelstein et al. 1983). Probes were hybridized to library filters $\left(1 \times 10^{6}\right.$ to $2 \times 10^{6} \mathrm{cpm} / \mathrm{ml}$ ) in Church buffer [7\% SDS, $1 \mathrm{~mm}$ EDTA, $0.5 \mathrm{M}$ sodium phosphate buffer $(\mathrm{pH} 7.2)]$ for $18-20 \mathrm{hr}$ at $65^{\circ} \mathrm{C}$.

\section{cDNA library screening}

Only colonies hybridizing with a given probe on two replicated library filters were considered positive. Subsequent secondary screening was performed to verify positive signals and to isolate clones for sequencing. The frequency of a given transcript in a library was determined by calculating the number of positive colonies per total cDNA colonies screened. For example, the frequency of $\beta$-actin transcripts in the egg library is 0.0011 (275 positive colonies $/ 250,000$ independent cDNA colonies screened). To estimate the total number of transcripts of a given gene in a single egg or embryo, the frequency of its occurrence in the egg or embryonic libraries was multiplied by the total number of poly $(\mathrm{A})^{+}$RNA molecules previously estimated to be present in a single egg or embryo, that is, $1.7 \times 10^{7}$ poly $(\mathrm{A})^{+}$ mRNA molecules in the mouse egg, $7 \times 10^{6}$ in the two-cell embryo, $1.3 \times 10^{7}$ in the eight-cell-stage embryo, and $3.4 \times 10^{7}$ in the early blastocyst (Clegg and Pikó 1983). Therefore, from the frequency of $\beta$-actin expression in the egg library of 0.0011 , the total number of actin molecules calculated in the mouse egg is estimated to be $(0.0011) 1.7 \times 10^{7}$ or 18,700 mRNA molecules.

\section{PCR analysis of CDNA libraries and Southern blotting}

Aliquots from each library were plated at high density $\left(2 \times 10^{6}\right.$ cfu) on Nuncleon $8.5 \times 8.5$-inch LB plates containing $70 \mu \mathrm{g} / \mathrm{ml}$ of ampicillin, incubated at $37^{\circ} \mathrm{C}$ for $16 \mathrm{hr}$, scraped into $50-\mathrm{ml}$ centrifuge tubes, and spun at $2500 \mathrm{~g}$. Plasmid DNA was obtained by use of a standard alkaline lysis method (Birnboim and Doly 1979), purified by CsCl gradient centrifugation (Sambrook et al. 1989|, and digested with MluI and SalI or PvuII as described by the manufacturer (New England Biolabs). Insert cDNA was purified by gel electrophoresis and separated from agarose with spin columns (Bio-Rad). For each PCR reaction, 10-50 ng of gel-purified insert cDNA was used. Primers for T7 and T3 polymerase promoters were synthesized in the Wistar Institute Nucleotide Synthesis Facility with the sequence published by Stratagene, and PCR was performed. Briefly, DNA template was denatured at $100^{\circ} \mathrm{C}$ for $15 \mathrm{~min}$ in $30 \mu \mathrm{l}$ of autoclaved $1 \times \mathrm{PCR}$ buffer [10 mM Tris- $\mathrm{HCl}$ (pH 8.3), $50 \mathrm{~mm} \mathrm{KCl,} 2.5 \mathrm{~mm} \mathrm{MgCl} 2,0.1$ $\mathrm{mg} / \mathrm{ml}$ of gelatin, $0.45 \% \mathrm{NP}-40,0.45 \%$ Tween 20 ], followed by the addition of PCR mix $[0.1 \mu \mathrm{g} / \mathrm{ml}$ of T7/T3 primer, $0.2 \mathrm{mM}$ dNTPs, 2 units of Thermalase, (IBI/Kodak)], and placed in a thermal cycler (Perkin-Elmer) for $35-45$ cycles at $94^{\circ} \mathrm{C}$ for 30 $\mathrm{sec}, 50^{\circ} \mathrm{C}$ for $30 \mathrm{sec}$, and $72^{\circ} \mathrm{C}$ for $1.0 \mathrm{~min}$. PCR reactions for cytokine primers were performed as recommended by Clonetech. PCR products were analyzed on $1-3 \%$ agarose gels and, when necessary, blotted onto nylon membrane (Sambrook et al. 1989), exposed to 1200 J of UV light using a Stratalinker 2400, and hybridized with appropriate probes.

\section{RNA transcription and subtractive hybridization}

The template for sense RNA was generated by digesting $\mathrm{CsCl}$ purified plasmid DNA with SalI for $18 \mathrm{hr}$ at $37^{\circ} \mathrm{C}$, followed by treatment with $5 \mu \mathrm{g} / \mathrm{ml}$ of proteinase $\mathrm{K}$ (Boehringer Mannheim) for $15 \mathrm{~min}$ at $56^{\circ} \mathrm{C}$, phenol-chloroform extraction, and ethanol precipitation. Template for antisense RNA was prepared as described above, except that MluI was used instead of SalI. RNA synthesis was performed with T7 or T3 RNA polymerase, and the reaction buffer was supplied by the manufacturer (Promega). For a single transcription reaction, 5-10 $\mu \mathrm{g}$ of template DNA was mixed with $1 \mathrm{~mm}$ each ATP, GTP, CTP, and either UTP or, for antisense RNA, biotin-UTP and UTP (10:1, respectively), and 100 units of polymerase in reaction buffer. Tracer $\left[{ }^{32} \mathrm{P}\right] \mathrm{UTP}$ was added at 1-2 $\mu \mathrm{Ci} /$ reaction. Following transcription, template was removed by DNase treatment $\left(50 \mathrm{ng} / \mathrm{ml}\right.$ at $37^{\circ} \mathrm{C}$ for 30 min 1, and the synthesized RNA, purified by phenol-chloroform extraction and ethanol precipitation, was quantified either spectrophotometrically or by calculating [ $\left.{ }^{32} \mathrm{P}\right] \mathrm{UTP}$ incorporation. Hybridization reactions between egg and two-cell-stage RNA were as described (Sive and St. John 1988). Briefly, $200 \mathrm{ng}$ of two-cell library-derived RNA was coprecipitated with $1 \mu \mathrm{g}$ of biotinylated egg library-derived RNA, resuspended in $4.5 \mu \mathrm{l}$ of hybridization buffer (250 mM HEPES (pH 7.5), 10 mM EDTA, $1 \%$ SDS] and $0.5 \mu \mathrm{l}$ of $5 \mathrm{M} \mathrm{NaCl}$, and hybridization was carried out for $48 \mathrm{hr}$ at $65^{\circ} \mathrm{C}$ under oil. Hybridization buffer without SDS was added $(50 \mu \mathrm{l})$, followed by $5 \mu \mathrm{l}$ of streptavidin $(1 \mathrm{mg} / \mathrm{ml}$; Bethesda Research Labs), and the reaction mixture was incubated for $5 \mathrm{~min}$ at room temperature, followed by phenol-chloroform extraction. The organic phase was extracted twice with $25 \mu$ l of hybridization buffer without SDS, and the aqueous phases were pooled, phenol/chloroform-extracted three more 
times, ethanol-precipitated, and washed. The two-cell libraryderived sense RNA remaining after hybridization with egg library-derived RNA was hybridized to a 10-fold excess of eightcell antisense RNA and treated as described above. The two-cell library-derived sense RNA remaining after hybridization and phenol-chloroform subtraction was reverse-transcribed and cloned into the pBS cloning vector as described above.

\section{Sequencing}

All cDNA clones were sequenced by use of the Sequenase kit (U.S. Biochemical) from the $5^{\prime}$ end with the $\mathrm{T} 7$ primer and the $3^{\prime}$ end with the T3 primer with $\left[{ }^{35} \mathrm{~S}\right] \mathrm{dATP}$ as described by the manufacturer. Sequencing reactions were run on a $10 \%$ polyacrylamide $/ 6 \%$ urea gel at $2000 \mathrm{~V}$ for $6-8 \mathrm{hr}$ and exposed to $\mathrm{X}$-ray film (X-Omat, Kodak) overnight at room temperature. All sequences were compared with those listed in the GenBank/ EMBL data bases by use of the WORDSEARCH and FASTA commands of the GCG sequence analysis program (Devereux et al. 1984).

\section{Acknowledgments}

We gratefully acknowledge J. Jessee (BRL) for the DH1OB bacteria and expert assistance in electroporation, Susan Johnson for her discussion and critical reading of this manuscript, and we thank Emma DeJesus and Geoffery Doerre for their technical help. D.S. and B.B.K. thank James Watson for his hospitality and the members of the James Laboratory at Cold Spring Harbor Laboratory, in particular Douglas Hanahan and his group, for their guidance and encouragement in the early phases of this study. This work was supported by U.S. Public Health Service from the National Institutes of Health grants (CA-10815, CA18470, HD-21335, and T32-CA09140 to J.R.)

The publication costs of this article were defrayed in part by payment of page charges. This article must therefore be hereby marked "advertisement" in accordance with 18 USC section 1734 solely to indicate this fact.

\section{References}

Abramczuk, J., D. Solter, and H. Koprowski. 1977. The beneficial effect of EDTA on the development of mouse one-cell embryos in chemically defined medium. Dev. Biol. 61: 738783.

Alonso, S., A. Minty, Y. Bourlet, and M. Buckingham. 1986. Comparison of three actin-coding sequences in the mouse; evolutionary relationships between actin genes of warmblooded vertebrates. J. Mol. Evol. 23: 11-22.

Bachvarova, R., E.M. Cohen, V. DeLeon, K. Tokunaga, S. Sakiyama, and B. Paynton. 1989. Amounts and modulation of actin mRNAs in mouse oocytes and embryos. Development 106: $561-565$.

Baumbach, G.A., R.T. Duby, and J.D. Godkin. 1990. N-glycosylated and unglycosylated forms of caprine trophoblast protein-1 are secreted by preimplantation goat conceptuses. Biochem. Biophys. Res. Com. 172: 16-21.

Birnboim, H.C. and J. Doly. 1979. A rapid alkaline extraction procedure for screening recombinant plasmid DNA. Nucleic Acids Res. 7: 1513-1523.

Clegg, K.B. and L. Pikó. 1983. Poly(A) length, cytoplasmic adenylation and synthesis of Poly(A) ${ }^{+}$RNA in early mouse embryos. Dev. Biol. 95: 331-341.
Crainie, M., L. Guilbert, and T.G. Wegman. 1990. Expression of novel cytokine transcripts in the murine placenta. Biol. Reprod. 43: 999-1005.

Cross, J.C. and R.M. Roberts. 1989. Porcine conceptuses secrete an interferon during the preattachment period of early pregnancy. Biol. Reprod. 40: 1109-1118.

Cross, J.C., C.E. Farin, S.F. Sharif, and R.M. Roberts. 1990. Characterization of the antiviral activity constitutively produced by murine conceptuses: Absence of placental mRNAs for interferon alpha and beta. Mol. Reprod. Dev. 26: 122-128.

Devereux, J., P. Haeberli, and O. Smithies. 1984. A comprehensive set of sequence analysis programs for the VAX. Nucleic Acids Res. 12: 387-395.

Dinarello, C. A. 1989. Interleukin-1 and its biologically related cytokines. Adv. Immunol. 44: 153-205.

Feinberg, A.P. and B. Vogelstein. 1983. A technique for radiolabelling DNA restriction endonuclease fragments to high specific activity. Analyt. Biochem. 132: 6-13.

Flynn, A., J.H. Finke, and M.L. Hilfiker. 1982. Placental mononuclear phagocytes as a source of interleukin-1. Science 218: $475-476$.

Giebelhaus, D.H., J.J. Heikkila, and G.A. Schultz. 1983. Changes in the quantity of histone and actin messenger RNA during the development of preimplantation mouse embryos. Dev. Biol. 98: 148-154.

Giebelhaus, D.H., H.M. Weitalauf, and G.A. Schultz. 1985. Actin mRNA content in normal and delayed implanting mouse embryos. Dev. Biol. 107: 407-413.

Gubler, U. and B.J. Hoffman. 1983. A simple and very efficient method for generating cDNA libraries. Gene 25: 263-269.

Hanahan, D., J. Jessee, and F.R. Bloom. 1991. Plasmid transformation of Escherichia coli and other bacteria. Methods Enzymol. 204: 63-113.

Hansen, T.R., K. Imakawa, H.G. Polites, K.R. Marotti, R.V. Anthony, and R.M. Roberts. 1988. Interferon RNA of embryonic origin is expressed transiently during early pregnancy in the ewe. J. Biol. Chem. 263: 12801-12804.

Henney, C.S. 1989. Interleukin 7: Effects on early events in lymphopoiesis. Immunol. Today 10: 170-173.

Hirano, T., S. Akira, T. Taga, and T. Kishimoto. 1990. Biological and clinical aspects of interleukin 6. Immunol. Today 11: 443-449.

Hogan, B., F. Constantini, and E. Lacy. 1986. Manipulating the mouse embryo: A laboratory manual. Cold Spring Harbor Laboratory, Cold Spring Harbor, New York.

Huarte, J., D. Berlin, and J.-D. Vassalli. 1985. Plasminogen activator in mouse and rat oocytes: Induction during meiotic maturation. Cell 43: 551-558.

Huarte, J., B. Dominique, A. Vassalli, S. Strickland, and J.-D. Vassalli. 1987. Meiotic maturation of mouse oocytes triggers the translation and polyadenylation of dormant tissue-type plasminogen activator mRNA. Genes \& Dev. 1: 1201-1211.

Imakawa, K., R.V. Anthony, M. Kazemi, K.R. Marotti, H.G. Polites, and R.M. Roberts. 1987. Interferon-like sequence of ovine trophoblast protein secreted by embryonic trophectoderm. Nature 330: 377-379.

Imakawa, K., T.R. Hansen, P.V. Malathy, R.V. Anthony, H.G. Polites, K.R. Marotti, and R.M. Roberts. 1989. Molecular cloning and characterization of complementary deoxyribonucleic acids corresponding to bovine trophoblast protein-1: A comparison with ovine trophoblast protein-l and bovine interferon-alpha II. Mol. Endocrinol. 3: 127-139.

Ko, M.S.H. 1990. An "equalized cDNA library" by the reassociation of short double-stranded cDNAs. Nucleic Acids Res. 18: 5705-5710.

Kramerov, D.A., A.A. Grigoryan, A.P. Ryskov, and G.P. 
Georgiev. 1979. Long double-stranded sequences (dsRNA-B) of nuclear pre-mRNA consist of a few highly abundant classes of sequences: Evidence from DNA cloning experiments. Nucleic Acids Res. 6: 697-713.

Krayev, A.S., D.A. Kramerov, K.G. Skryabin, A.P. Ryskov, A.A. Bayev, and G.P. Georgiev. 1980. The nucleotide sequence of the ubiquitous repetitive DNA sequence Bl complementary to the most abundant class of mouse fold-back RNA. Nucleic Acids Res. 8: 1201-1215.

Kuff, E. and J.W. Fewell. 1985. Intracisternal A-particle gene expression in normal mouse thymus tissue: Gene products and strain-related variability. Mol. Cell. Biol. 5: 474-483.

Larin, Z., A.P. Monaco, and H. Lehrach. 1991. Yeast artificial chromosome libraries containing large inserts from mouse and human DNA. Proc. Natl. Acad. Sci. 88: 4123-4127.

Lee, J.F., J. Pintar, and A. Efstratiadis. 1990. Pattern of the insulin and insulin-like growth factor II gene expression during early mouse embryogenesis. Development 110: 151-159.

Lotem, J., Y. Shabo, and L. Sachs. 1991. The network of hemopoietic regulatory proteins in myeloid cell differentiation. Cell Growth Differ. 2: 421-427.

Lueders, K.K. and E.L. Kuff. 1980. Intracisternal A-particle genes: Identification in the genome of Mus musculus and comparison of multiple isolates from a mouse gene library. Proc. Natl. Acad. Sci. 77: 3571-3575.

Masuhiro, K., N. Matsuzaki, E. Nishino, T. Taniguchi, T. Kameda, Y. Li, F. Saji, and D. Tanizawa. 1991. Trophoblastderived interleukin-1 (IL-1) stimulates the release of human chorionic gonadotropin by activating IL- 6 and IL- 6 receptor system in the first trimester human trophoblasts. I. Clin. Endocrinol. Metab. 72: 594-601.

Mietz, J.A., Z. Grossman, K.K. Lueders, and E.L. Kuff. 1987. Nucleotide sequence of a complete mouse intracisternal A-particle genome: Relationship to known aspects of particle assembly and function. J. Virol. 61: 3020-3029.

Monk, M., M. Bowbelik, and S. Lehner. 1987. Temporal and regional changes in DNA methylation in the embryonic, extraembryonic and germ cell lineages during mouse embryo development. Development 99: 371-382.

Morrow, M.A., G. Lee, S. Gillis, G.D. Yancopoulos, and F.W. Alt. 1992. Interleukin-7 induces $\mathrm{N}-m y c$ and c-myc expression in normal precursor B lymphocytes. Genes \& Dev. 6: 61-70.

Murphy, D., P.M. Brickell, D.S. Latchman, K. Willison, and P.W.J. Rigby. 1983. Transcripts regulated during normal embryonic development and oncogenic transformation share a repetitive element. Cell 35: 865-871.

Murray, R., F. Lee, and C.P. Chiu. 1990. The genes for leukemia inhibitory factor and interleukin- 6 are expressed in mouse blastocysts prior to the onset of hemopoiesis. Mol. Cell Biol. 10: 4953-4956.

Namen, A.E., S. Lypton, K. Hjerrild, J. Wignall, D.Y. Mochizuki, A. Schmierer, B. Mosley, C.J. March, D. Urdal, S. Gillis, D. Cosman, and R.G. Goodwin. 1988. Stimulation of B-cell progenitors by cloned murine interleukin-7. Nature 333: 571573.

Nieder, G.L. 1990. Protein secretion by the mouse trophoblast during attachment and outgrowth in vitro. Biol. Reprod. 43: 251-259.

Oppenheim, J.J., E.J. Kovacs, K. Matsushimi, and S.K. Durum. 1986. There is more than one interleukin 1. Immunol. Today 7: 45-56.

Pikó, L. and K.B. Clegg. 1982. Quantitative changes in total RNA, total poly(A), and ribosomes in early mouse embryos. Dev. Biol. 89: 362-378.

Pikó, L. and K.D. Taylor. 1981. Amounts of mitochondrial DNA and abundance of some mitochondrial gene transcripts in early mouse embryos. Dev. Biol. 123: 364-374.

Pikó, L., M.D. Hammons, and K.D. Taylor. 1984. Amounts, synthesis, and some properties of intracisternal A particlerelated RNA in early mouse embryos. Proc. Natl. Acad. Sci. 81: 488-492.

Poznanski, A.A. and P.G. Calarco. 1991. The expression of intracisternal A particle genes in the preimplantation mouse embryo. Dev. Biol. 143: 271-281.

Rappolee, D.A., C.A. Brenner, R. Schultz, D. Mark, and Z. Werb. 1988. Developmental expression of PDGF, TGF- $\alpha$, and TGF- $\beta$ genes in preimplantation mouse embryos. Science 241: $1823-1825$.

Rickles, R.J., A.L. Darrow, and S. Strickland. 1988. Molecular cloning of complementary DNA to mouse tissue plasminogen activator mRNA and its expression during F9 teratocarcinoma cell differentiation. J. Biol. Chem. 263: 1563-1569.

Roberts, R.M., K. Imakawa, Y. Niwano, M. Kazemi, P.V. Malathy, T.R. Hansen, A.A. Glass, and L.H. Kronenberg. 1989. Interferon production by the preimplantation sheep embryo. I. Interferon Res. 9: 175-187.

Rupp, R.A.W. and H. Weintraub. 1991. Ubiquitous Myo-D transcription at the midblastula transition precedes inductiondependent Myo-D expression in presumptive mesoderm of $X$. laevis. Cell 65: 927-937.

Sambrook, J., E.F. Fritsch, and T. Maniatis. 1989. Molecular cloning: A laboratory manual, 2nd ed. Cold Spring Harbor Laboratory, Cold Spring Harbor, New York.

Sawicki, J.A., T. Magnuson, and C. Epstein. 1981. Evidence for expression of the paternal genome in the two-cell mouse embryo. Nature 294: 450-451.

Schultz, G.A. 1986. Utilization of genetic information in the preimplantation mouse embryo. In Experimental approaches to mammalian embryonic development (ed. J. Rossant and R.A. Pedersen|, pp. 239-265. Cambridge University Press, Cambridge, England.

Sehgal, P.B. 1990. Interleukin 6 in infection and cancer. Proc. Soc. Exp. Biol. Med. 195: 183-191.

Sive, H. and T. St. John. 1988. A simple subtractive hybridization technique employing photoactivatable biotin and phenol extraction. Nucleic Acids Res. 16: 10937.

Strickland, S., J. Huarte, D. Belin, A. Vassalli, R.J. Rickles, and J.-D. Vassalli. 1988. Antisense RNA directed against the 3' noncoding region prevents dormant mRNA activation in mouse oocytes. Science 241: 680-684.

Taniguchi, T., N. Matsuzaki, T. Kameda, K. Shimoya, T. Jo, F. Saji, and O. Tanizawa. 1991. The enhanced production of placental interleukin-1 during labor and intrauterine infection. Am. I. Obstet. Gynecol. 165: 131-137.

Taylor, K.D. and L. Pikó. 1987. Patterns of mRNA prevalence and expression of B1 and B2 transcripts in early mouse embryos. Development 101: 877-892.

-1990. Quantitative changes in cytoskeletal $\beta$-actin and $\gamma$-actin mRNAs and apparent absence of sarcomeric actin gene transcripts in early mouse embryos. Mol. Reprod. Dev. 26: 111-121.

Telford, N.A., A.J. Watson, and G.A. Schultz. 1990a. Transition from maternal to embryonic control in early mammalian development: A comparison of novel genes. Mol. Reprod. Dev. 26: 90-100.

Telford, N.A., A. Hogan, C.R. Franz, and G.A. Schultz. 1990b. Expression of genes for insulin and insulin-like growth factors and receptors in early postimplantation mouse embryos and embryonal carcinoma cells. Mol. Reprod. Dev. 27: 8192.

Vasseur, M., H. Condamine, and P. Duprey. 1985. RNAs con- 
taining B2 repeated sequences are transcribed in the early stages of mouse embryogenesis. EMBO /. 4: 1749-1753.

Warner, C.M. 1977. RNA polymerase activity in preimplantation mammalian embryos. In Development in mammals (ed. M.H. Johnson), pp. 99-136. Elsevier/North-Holland, New York.

Welsh, J., J.-P. Liu, and A. Efstratiadis. 1990. Cloning of PCRamplified total cDNA: Construction of a mouse oocyte cDNA library. Genet. Anal. Tech. Appl. 7: 5-17.

Weng, D.E., R.A. Morgan, and J.D. Gearhart. 1989. Estimates of mRNA abundance in the mouse blastocyst based on cDNA library analysis. Mol. Reprod. Dev. 1: 233-241. 


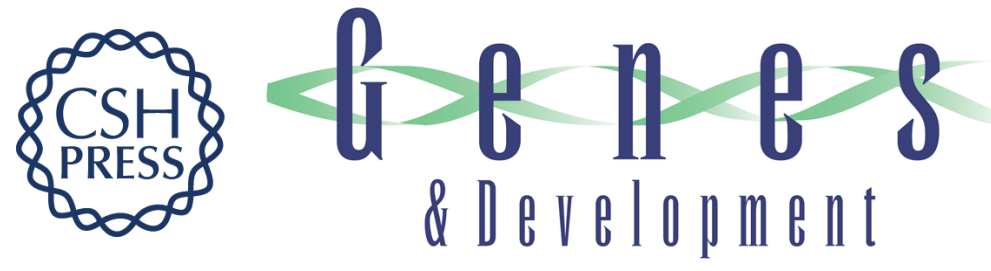

\section{Gene expression during preimplantation mouse development.}

J L Rothstein, D Johnson, J A DeLoia, et al.

Genes Dev. 1992, 6:

Access the most recent version at doi:10.1101/gad.6.7.1190 $\begin{array}{ll}\text { References } & \begin{array}{l}\text { This article cites } 61 \text { articles, } 18 \text { of which can be accessed free at: } \\ \text { http://genesdev.cshlp.org/content/6/7/1190.full.html\#ref-list-1 }\end{array}\end{array}$

License

Email Alerting

Receive free email alerts when new articles cite this article - sign up in the box at the top Service right corner of the article or click here.

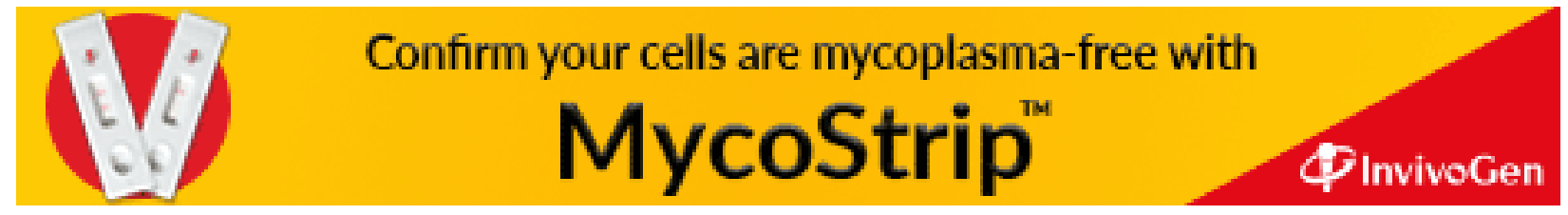

